\title{
Science Virtual Test: A Computer-Based Test to Measure Students' Critical Thinking on Living Things and Environmental Sustainability Theme
}

\author{
Harry Firman \\ Department of Chemistry Education \\ FPMIPA Universitas Pendidikan Indonesia \\ J1. Dr. Setiabudi No 229, Bandung 40154, Indonesia \\ harry_firman@upi.edu
}

\author{
Lilit Rusyati \\ International Program on Science Education (IPSE) \\ FPMIPA Universitas Pendidikan Indonesia \\ Jl. Dr. Setiabudi No 229, Bandung 40154, Indonesia \\ lilitrusyati@upi.edu
}

\begin{abstract}
This research is motivated by the importance of multiplechoice questions that indicate the elements and sub-elements of critical thinking. The method is Research and Development (R\&D) to describe a process that used to develop and validate educational products. This research synergies between the lecturers and students that aims to develop a critical thinking virtual test made with the principle of student-centered software. The study is three years include (1) development phase, (2) trial test phase, and (3) the promotion phase of the final product. The development phase consists of a junior high school science curriculum analysis and production of virtual science about critical thinking test. Trial test phase consisted of limited test to one school and extensive trial test at three schools. Promotion phase the final product consists of a workshop on science teachers about science virtual test and its application on junior high school students. Results of the study in the first year is a product of science virtual test with the theme "Living Things and Environmental Sustainability" in VII grade. General characteristic of multiple choices to measure critical thinking are made by eight elements and 26 sub elements that developed by Inch et al.; complete by relevant information; and have validity and reliability more than "enough". Furthermore, specific characteristic of multiple choices to measure critical thinking are information in form science comic, table, figure, article, and video; correct structure of language, add source of citation, and question can guide student to critical thinking logically.
\end{abstract}

Keywords - environmental sustainability, computer-based test, living things, science virtual test, critical thinking

\section{INTRODUCTION}

Nowadays, Information and Computer Technology (ICT) has became importat thing in daily life especially in teaching and learning.

Science education has important role to guide students in life. The philosophies of science are fact, concept, principle, theory, and law. Science processes are way to get, to develop, and to apply knowledge that included effort way, thinking way, problem solving, and attitude. So that, science has formulate systematically, especially based on observation, experiment, and induction [1].

Regulation of the Minister of National Education stated that students should to: (1) build and apply of information or knowledge logically, critically, creatively, and innovative; (2) problem solving that use skill of logic thinking, critical, creative, and innovative; (3) analyze and solve complex problem. In other hand, student not only can critical thinking but also can share of argumentation [2]. Students can communicate their thinking and collecting all information [3].

Critical thinking not only can develop in learning activity but also should support by evaluation or test, because evaluation or test is part to include in learning at the class [4]. Moreover, the basic of education is evaluation. So that, item test make by critical thinking indicators [5]. Nowadays, test item not guide student to explore their critical thinking skill. In line statement, one problem in testing is test item not focus on important thing that should to measure [4].

\section{METHOD}

The method that used in this research is the Research and Development $(\mathrm{R} \& \mathrm{D})$ to describe a process used to develop and validate educational products. Subjects in this study were junior high school students of VII, VIII, and IX grades which will conduct a trial test of legibility and virtual science test questions on the theme "Living Things and Environmental Sustainability ". The instrument that used as a tool to capture the necessary data are sheet of an expert judgment, sheet of legibility test, and package about science virtual multiplechoice test of critical thinking with four possible answers based on eight elements of Inch's critical thinking [3].

\section{RESULTS AND DISCUSSION}

Result of this study are describe about characteristic of virtual test that use to measure student's critical thinking on theme "Living Things and Environmental Sustainability", analyze result of legibility test by students and science teachers, analyze result of expert judgment by science teachers, analyze result of trial test about virtual test at junior high school.

A. Analysis of Core Competence (KI) and Basic Competency (KD) on the theme of "Living Things and Environmental Sustainability" in Junior High School 
The theme chosen in this study is "Living Things and Environmental Sustainability". The first stage is done before designing the blueprint for a science virtual test is to analyze the science curriculum in Junior High School that represent with the theme of the research. Analysis has been done on the junior science syllabus of VII, VIII, and IX grades, but research in this year, focus on science VII grade for the production of virtual tests and trials in junior high school students. The theme is covering the topic of the characteristics of living things; diversity and conservation; energy concepts; ecosystems; environmental pollution; as well as global warming.

\section{B. Characteristics of Science Virtual Test on Theme "Living Things and Environmental Sustainability"}

In the first year, science virtual test on the theme "Living Things and Environmental Sustainability" focus in VII grade. Draft of a research instrument made by analysis of Core Competencies and the Basic Competency in Junior High School VII grade. Science virtual test in in this study was produced using the program Adobe Flash Player 9. Slide the opener in the virtual test contains the title "Quiz Ecosystems and Environment" and the identity of the student (name and class) presented in the following figure.
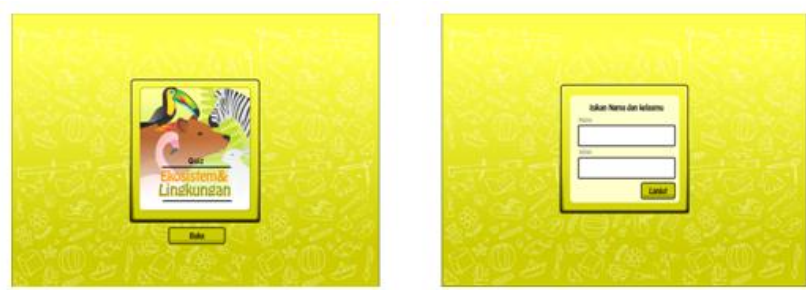

Fig. 1. Opening Slide and Student Identity

The next slide shows the identity of the researcher and the research team, and equipped with the "zoom out", "cancel (x)" and "start" is presented in Figure 2.

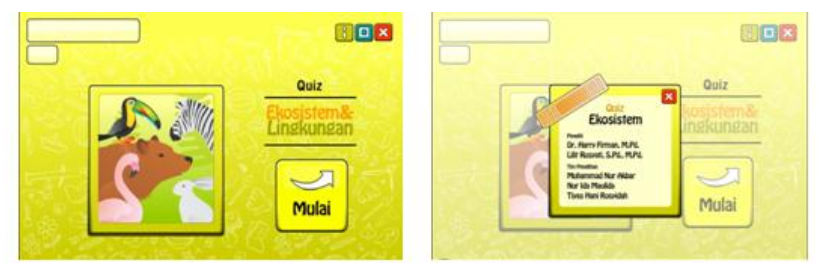

Fig. 2. Starting Slide and Researcher Identity

C. Analysis The Expert Judgment of Science Virtual Test on Theme "Living Things and Environmental Sustainability" by Science Teacher

Expert judgment conducted by five science teachers and one doctor. There are five indicators that used by teachers: (1) Representative by critical thinking elements, (2) True answer, (3) Information or article is useful, (4) Structure of writing is good, (5) Distractor is clear. There are suggestions from expert judgment: use active sentence, consistent when use month/year, figure make clearly, dialogue make clearly, comic and article make clearly.

D. Analysis The Legibility Test of Science Virtual Test on Theme "Living Things and and Environmental Sustainability" by Students and Science Teachers

Virtual test legibility conducted by three science teachers and four students. There are five indicators: (1) Article/comic/figure/ video is clear, (2) Question is clear, (3) Option is clear, (4) Relationship between question and answer, and (5) No difficult or ambiguity concept. According to virtual test legibility, there are suggestions: add more figures, use simple concept, use simple article, comic clearly, structure of writing, optional no longer, simple option, high volume and clear video.

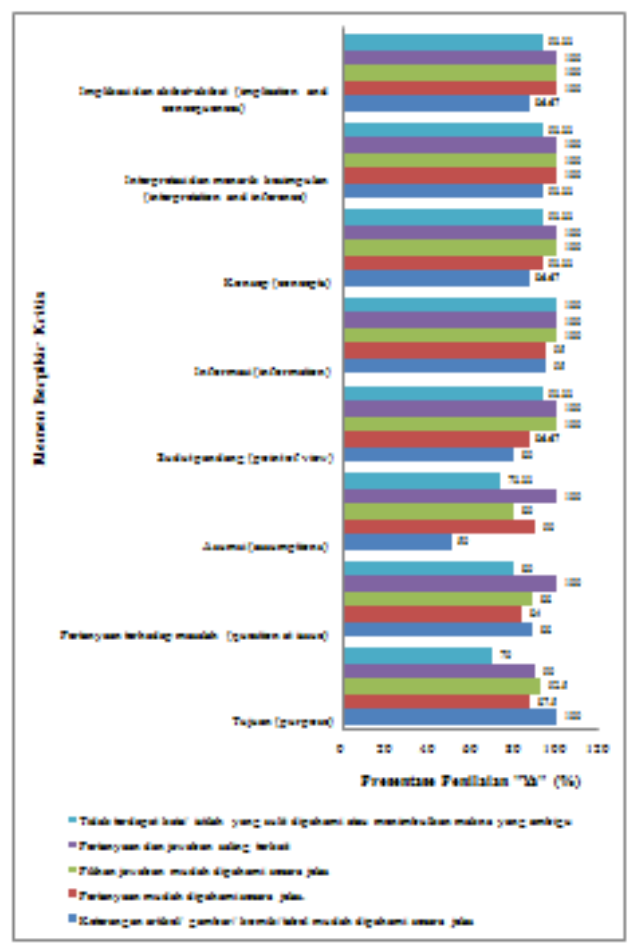

Fig. 3. Analysis The Legibility Test of Science Virtual Test

\section{E. Analysis The Trial Test Results of Science Virtual Test on Theme "Living Things and Environmental Sustainability"}

Science virtual test package contains 31 multiple-choice questions are made based elements and sub-elements of critical thinking. Trial test was conducted on 23 junior high students. The trial test results were analyzed using the program AnatesV4. Based on the analysis, the result that the reliability of the questions test is 0.43 . In addition, it was stated that the problems are divided into three categories: questions accepted, accepted with revision, and not accepted (discarded). Category of questions that received has positively correlated with significant and very significant commentary as much as 17 questions; about the revision received positively correlated significantly with the under interpretation as many as 11 questions; and not accepted (discarded) has a negative correlation as much as 3 questions. 
General characteristic of test item to measure student's critical thinking are:

1. Based on eight elements and 26 sub element that has been developed by Inch's critical thinking and connection one to others.

2. Completed by relevant information.

3. Validity and reliability more than "enough".

Furthermore, specific characteristic of multiple choices to measure critical thinking are information in form science comic, table, figure, article, and video; correct structure of language, add source of citation, and question can guide student to critical thinking logically.

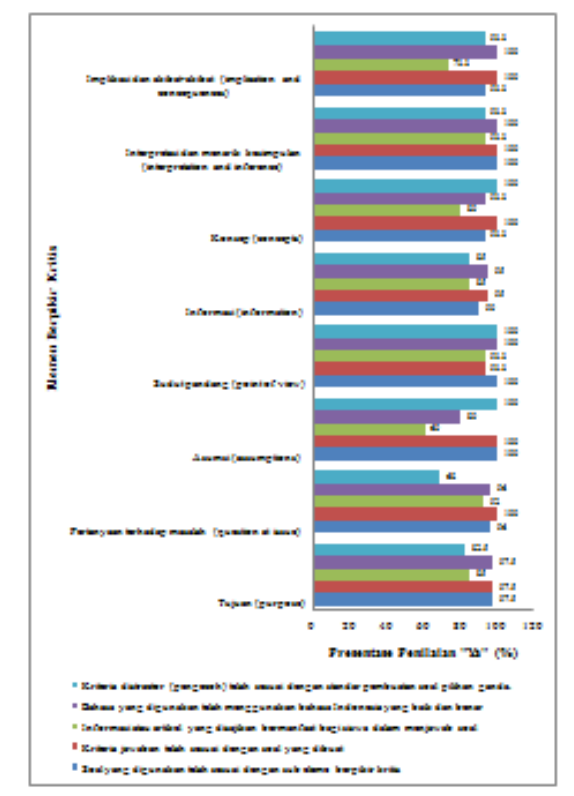

Fig. 4. Analysis The Trial Test Results of Science Virtual Test
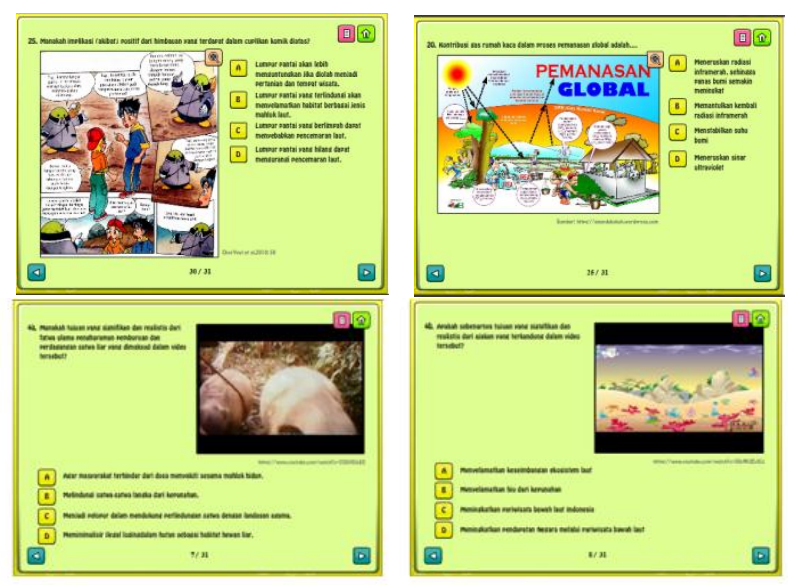

Fig. 5. Science Virtual Test

Indicators of a student has the ability to think critically on an element "purpose" is good, thus the student should be able to declared the purpose clearly, distinguished the main objective with other objectives, stated objectives on target, and stated the significant and realistic objectives [6]. Indicators on an element "question at issue" are students can state questions clearly and precisely, ask questions with some way to explaining the meaning and scope of the problem, can state sub-questions, and can identify question problem. Element "assumptions" are the prediction and point of view for sharing to the other. For example, someone try to be fair. Element "point of view" of reasoning and thinking is a part of the critical thinking that involves interpretation process and understanding something.

Element "information" is developing ideas and synthesizing new ideas. Critical thinking is a mental process to analyze or evaluate information. The information can be obtained from observation, experience, common sense or communication. Indicators of a student has the ability to think critically on an elements "concepts" that students can identify key concepts and states clearly, stating the alternative concept or definition of alternative concepts, and can use concepts carefully and thoroughly [6]. The concept is an abstraction that describes the characteristics, attributes of the same characters from a group or fact, such as a process, events, objects or phenomena in nature that make different from other groups[7]. Element "interpretation and inference" is student can conclude based on the evidence, check the consistency of the conclusions, and can identify assumptions that may lead to the conclusion Indicators of a student has the ability to think critically on an element "implication and concequences" that students can discover the implications and the consequences that follow the argument, expressed both positive and negative implications, and can consider all the consequences which may occur [6].

Critical thinking is developed in a learning-based active study. It is intended that students understand not only the content but also able to think, read, and write critically [8]. Critical thinking is also the competence to graduate from technology program. Critical thinking is very close to the scientific thought, for example when students use scientific methods to study or investigate the nature, the students learn to be critical when looking for solutions to a problem, understand the limitations and strengths of data to make inferences [9].

\section{CONCLUSION}

General characteristic of multiple choices to measure critical thinking are made by eight elements and 26 sub elements that developed by Inch et al.; complete by relevant information; and have validity and reliability more than "enough". Furthermore, specific characteristic of multiple choices to measure critical thinking are information in form science comic, table, figure, article, and video; correct structure of language, add source of citation, and question can guide student to critical thinking logically. 


\section{References}

[1] Mahmuddin. (2009). Pendekatan Sains, Teknologi, dan Masyarakat dalam Pembelajaran. [Online]. Tersedia: http://pendekatan-sainsteknologi-dan-masyarakat-dalam-pembelajaran/ [29 September 2011].

[2] Peraturan Menteri Pendidikan Nasional. (2006). Standar Kompetensi Lulusan. [Online]. Tersedia: http://litbang.kemdiknas.go.id [29 September 2011].

[3] Inch, E.S., et al. (2006). Critical Thinking \& Communication, The Use of Reason in Argument. United States of America: Pearson Education.

[4] Jacobs, L. C. dan Chase, C. I. (1992). Development and Using Test Effectively. San Fransisco: Jossey-Bass Publishers.

[5] Arikunto, S. (2001). Dasar-Dasar Evaluasi Pendidikan. Jakarta: PT Bumi Aksara.
[6] R. Paul and L. Elder. "The Analysis \& Assessment of Thinking (Helping Students Assess Their Thinking)." The Critical Thinking Community, Foundation for Critical Thinking (2008).

[7] N. Rustaman, Biology Teaching and Learning Strategies (UM Press, Malang, 2005), pp. 49-57.

[8] S. Chaplin, International Journal for The Scholarship of Teaching and Learning 1, 10 (2007).

[9] Chanchaichaovivat, B. Panijpan, and P. Ruenwongsa, Asian Journal of Food and Agro-Industry 2, 424-443 (2009). 